RESEARCH PAPER

\title{
How Philip Morris built Marlboro into a global brand for young adults: implications for international tobacco control
}

\author{
N Hafez, P M Ling
}

Tobacco Control 2005;14:262-271. doi: 10.1136/tc.2005.011189

See end of article for authors' affiliations .....................

Correspondence to: Pamela $M$ Ling, MD, MPH, Box 0320, University of California, San Francisco, San Francisco, CA 941430320, USA; pling@ medicine.ucst.edu

Received 14 January 2005 Accepted 9 February 2005
Objective: To describe Philip Morris' global market research and international promotional strategies targeting young adults.

Methods : Analysis of previously secret tobacco industry documents.

Results: Philip Morris pursued standardised market research and strategic marketing plans in different regions throughout the world using research on young adults with three principle foci: lifestyle/ psychographic research, brand studies, and advertising/communication effectiveness. Philip Morris identified core similarities in the lifestyles and needs of young consumers worldwide, such as independence, hedonism, freedom, and comfort. In the early 1990s Philip Morris adopted standardised global marketing efforts, creating a central advertising production bank and guidelines for brand images and promotions, but allowing regional managers to create regionally appropriate individual advertisements.

Conclusions: Values and lifestyles play a central role in the global marketing of tobacco to young adults. Worldwide counter marketing initiatives, coupled with strong, coherent global marketing policies such as the Framework Convention on Tobacco Control, are needed to break associations between young adult values and tobacco brands. As globalisation promotes the homogenisation of values and lifestyles, tobacco control messages that resonate with young adults in one part of the world may appeal to young adults in other countries. Successful tobacco control messages that appeal to young people, such as industry denormalisation, may be expanded globally with appropriate tailoring to appeal to regional values. nternational tobacco promotion and marketing acts as both a lens for viewing the effects of globalisation as well as a vector for its progression. As global communication through television, internet, and other mass media affects the lifestyle of consumers worldwide, tobacco companies track and respond to shifts in the needs, wants, and lifestyles of their targets. Simultaneously, the tobacco industry contributes to the development of a global consciousness through aggressive marketing campaigns connecting its brand images to common values and lifestyles. ${ }^{1}$

Prior studies describe the emergence of new markets for tobacco products and the exportation of successful marketing strategies from developed countries to the developing world. However, much of the research to date has been region specific, highlighting the marketing efforts and strategies in specific countries such as Sri Lanka, ${ }^{2}$ China, ${ }^{3}$ Hungary, ${ }^{4}$ Myanmar, ${ }^{5}$ or Indonesia. ${ }^{6}$ While some international cigarette brands are concentrated in certain regions (such as State Express 555 in Asia), ${ }^{78}$ others, such as Marlboro and Camel, are recognised all over the world, particularly among the young..$^{8-13}$

Basic marketing theory states that global companies must decide how best to adapt their promotional efforts to the local regions in which they sell. Some global companies adopt a standardized approach to promotions, using the same basic advertisements and promotional strategies across markets. An opposing strategy is to develop adapted promotions, where companies develop ads and promotional strategies to meet conditions particular to local markets. Standardised promotional efforts are usually lower in cost and relatively easier to manage than adapted promotions, which require increased management but may result in more effective communications efforts. ${ }^{14}$
The decision to adopt a standardised or adapted approach affects how companies manage their brands in different parts of the world. Brand terminology and definitions are summarised in table 1 . Companies with a standardised promotional approach will strive for customers to perceive a similar brand image across markets while those adopting an adaptive approach may allow customers to perceive differing images for the same brand with the goal of establishing the highest equity for that brand in each local market.

The emergence of market economies throughout Eastern Europe and the Far East in the 1990s provided a new opportunity for tobacco companies to expand their global reach. ${ }^{15}$ Philip Morris International is the world's leading tobacco company outside of the USA; its brands include Marlboro, the world's best selling international cigarette brand. ${ }^{16}$ Young adults are a key target market for tobacco companies, ${ }^{17}$ and they are a key target for Marlboro both in the USA and internationally. ${ }^{18}$ We examined Philip Morris's global market research efforts and worldwide advertising and promotion strategies targeting young adults (age 18-30 years) developed during the 1990s to determine whether Philip Morris used an adaptive or standardised global promotional strategy.

Our analysis was guided by the following principle research questions: (1) What major types of market research does Philip Morris conduct internationally? (2) How did this research inform Philip Morris's strategy in different regions of the world? (3) Did Philip Morris pursue adaptive or standardised promotional strategies for Marlboro? We found

Abbreviations: MISTA, Marlboro International Study for Testing and Advertising; MWCRC, Marlboro Worldwide Creative Review Committee; YAMS, young adult male smoker 


\begin{tabular}{|c|c|c|}
\hline Term & Definition & Examples \\
\hline Brand equity & $\begin{array}{l}\text { A set of brand assets that adds or subtracts value to a product. These assets } \\
\text { can include brand loyalty, awareness, perceived quality, brand image, } \\
\text { and other proprietary brand assets such as the number of trademarks or } \\
\text { patents associated with the brand. } 78 \text { Brand equity can also be quantified by } \\
\text { comparing the price differential from a branded product with an equivalent } \\
\text { non-branded product }\end{array}$ & $\begin{array}{l}\text { The price differential between a pack of Marlboro versus } \\
\text { Parliament versus general cigarettes, all manufactured by } \\
\text { Philip Morris, results from differences in brand equity } \\
\text { between the brands }\end{array}$ \\
\hline Brand image & $\begin{array}{l}\text { The current associations consumers make with and the attitudes they hold } \\
\text { toward a particular brand }{ }^{14}\end{array}$ & $\begin{array}{l}\text { Consumers associate Ben \& Jerry's ice cream with ethics and } \\
\text { environmentalism, Mercedes automobiles with luxury, and } \\
\text { Marlboro cigarettes with masculinity and cowboys }\end{array}$ \\
\hline Brand identity & $\begin{array}{l}\text { The associations and attitudes that brand strategists hope to instil or } \\
\text { maintain in consumers with respect to their brand. In contrast to current } \\
\text { brand image, brand identity represents the ideal future image that brand } \\
\text { managers strive to create for their brand." Brand identity elements include } \\
\text { product scope, attributes, quality, uses, users, country of origin, organisation } \\
\text { attributes, local versus global, brand personality, customer-brand } \\
\text { relationships, visual image and brand heritage" }\end{array}$ & $\begin{array}{l}\text { While consumers may currently associate McDonald's with } \\
\text { unhealthy fast foods, McDonald's brand managers are } \\
\text { currently promoting a new identity that highlights healthy } \\
\text { options such as salads and bottled water. McDonald's brand } \\
\text { identity is built through a system of commercials, logos, } \\
\text { characters (Ronald...), "Mc" named menu items, etc }\end{array}$ \\
\hline $\begin{array}{l}\text { Brand } \\
\text { positioning }\end{array}$ & $\begin{array}{l}\text { The part of the brand identity and value proposition that is to be actively } \\
\text { communicated to the target audience and that demonstrates an advantage } \\
\text { over competing brands }\end{array}$ & $\begin{array}{l}\text { Kool cigarettes are positioned as the strongest menthol } \\
\text { cigarette or Apple computers are positioned as more user } \\
\text { friendly than PCs }\end{array}$ \\
\hline
\end{tabular}

that market research conducted by Philip Morris to develop advertising campaigns fell into three primary categories: (1) lifestyle/psychographic research, (2) brand studies, and (3) advertising/communication effectiveness. ${ }^{19}$ Philip Morris's general research on young adult lifestyles and values informed how Marlboro's brand equity was measured in different regions. Philip Morris's market research demonstrated remarkable similarities in core values among young adults in Asia, Europe, and the USA. This convergence of values and lifestyles led to the development of standardised promotions plans for Marlboro, the development of a single global brand identity for Marlboro, a single worldwide creative brief, and a central advertising pool that allowed regional variations in individual executions. Philip Morris' standardised promotion strategies suggest ways policymakers can develop more effective marketing restrictions and tobacco control counter marketing efforts.

\section{METHODS}

We searched tobacco industry document archives from the University of California, San Francisco Legacy Tobacco Documents Library (legacy.library.ucsf.edu), and Tobacco Documents Online (www.tobaccodocuments.org). Tobacco industry document internet sites (Philip Morris, www.pmdocs.com; RJ Reynolds, www.rjrtdocs.com; Lorillard, www.lorillarddocs.com; and Brown \& Williamson; www. bwdocs.com) were searched for supplemental information when documents could not be retrieved from the non-industry sites.

Searches were conducted between June 2003 and June 2004. Initial search terms included: "global" and "international" and "research" and "market" and "strateg"". Initial searches yielded thousands of documents; we reviewed those documents related to general global marketing strategies of three major US tobacco companies: Philip Morris, RJ Reynolds, and Brown \& Williamson. Searches were repeated and focused using standard techniques. ${ }^{20}$ Further "snowball" searches for contextual information on relevant documents were conducted using names, project titles, brand names, document locations, dates, and reference (Bates) numbers. This analysis is based on a final collection of 227 research reports, presentations, memorandums, advertisements, and plans, which were analysed in detail. Global marketing plans were identified for three tobacco companies, but the bulk of the market research documents recovered were from Philip Morris; this analysis focuses on Philip Morris's global strategies targeting young adults. We focused on internal strategic planning, brand plans, market share, and other marketing research that guided the development of Philip Morris' global Marlboro advertising and promotional campaign. Philip Morris conducted other international market research devoted to product development (such as concept tests, product tests, concept deliverability tests, name tests, pack tests,) and sales (price tests, sales simulations) that was beyond the scope of this inquiry. ${ }^{19}$ The authors reviewed the documents and wrote summary memoranda. Common themes were identified and discussed; differences were resolved primarily by gathering additional data. Information found in industry documents was triangulated with data from searches of the published literature, tobacco company annual reports, and online search engines (such as Google).

Table 2 Types of consumer focused market research Philip Morris conducted for Marlboro

\begin{tabular}{ll}
\hline Lifestyle & Identifies the key needs and values of target consumers. This research often includes insights \\
& into popular behaviours, pastimes, peer relationships, thoughts, fears, political leanings, family \\
life, goals and aspirations, and attitudes toward smoking & Examines a brand's image though consumer surveys and focus groups. Determining consumer \\
Brand & perceptions of Marlboro in different regions was a particular focus of Philip Morris' \\
& international market research; this research was used to develop a global Marlboro brand \\
identity and positioning & \\
Communications & Measures consumer reactions to specific advertisements, promotional campaigns, or \\
& sponsorship efforts. Offen consists of copy testing or eliciting reactions to actual or prototype \\
& advertisements. Popular measurement criteria include recall (ability of the advertisement to \\
& attract attention and interest), persuasion (ability of the advertisement to influence decisions), \\
& and communication effectiveness (effectiveness in conveying the intended message)
\end{tabular}


Table 3 Philip Morris market research studies into consumer lifestyles, brand images, and communication efforts

\begin{tabular}{|c|c|c|c|}
\hline Title & Type & Year Author & Country \\
\hline $\begin{array}{l}\text { Cigarette Pricing And Strategic } \\
\text { Brand Positioning }\end{array}$ & Lifestyle & 1985 Noresearch & Japan \\
\hline Image Study Germany & Brand image & 1985 PMI & Germany \\
\hline Global Generation Of YAS & Lifestyle & 1989 Leo Burnett & USA, Germany, Switzerland, Japan \\
\hline $\begin{array}{l}\text { Exploratory Marlboro Strategic } \\
\text { Research }\end{array}$ & Lifestyle/communications & 1989 Leo Burnett & Australia \\
\hline $\begin{array}{l}\text { Values, Lifestyles And Brand } \\
\text { Images Among Taiwanese YAMS }\end{array}$ & $\begin{array}{l}\text { Lifestyle/brand/ } \\
\text { communications }\end{array}$ & 1991 RI Asia-Hamel; Prahalad & Taiwan \\
\hline $\begin{array}{l}\text { Marlboro Red EEC Marketing } \\
\text { Review }\end{array}$ & Lifestyle & 1992 PM-EEC & France, Spain, Netherlands, Belgium \\
\hline Young Male Adults In Japan & Lifestyle & 1992 LBC & Japan \\
\hline Young Adult Smokers In Italy & Lifestyle/brand image & 1992 PM-EEC; Herzog,Pr & Italy \\
\hline Marlboro Brand Review & Brand image & $\begin{array}{l}1992 \text { Tmd Carat, Marlboro Brand } \\
\text { Group }\end{array}$ & UK' \\
\hline $\begin{array}{l}\text { Motorsports Sponsorship } \\
\text { Marketing Review }\end{array}$ & Communications & 1992 PM-EEC & Europe \\
\hline Hong Kong YAMS Study & $\begin{array}{l}\text { Lifestyle/brand/ } \\
\text { communications }\end{array}$ & 1993 RI Asia/PM Asia & Hong Kong \\
\hline $\begin{array}{l}\text { International Marlboro Image } \\
\text { Dynamics Study }\end{array}$ & Lifestyle/brand image & 1993 Sinus; Lebensweittorschung & (Proposal for multiple countries) \\
\hline $\begin{array}{l}\text { International Marlboro Image } \\
\text { Dynamics Study }\end{array}$ & Lifestyle & 1993 Sinus (inferred) & Saudi Arabia \\
\hline Marlboro Image Dynamics Study & $\begin{array}{l}\text { Lifestyle/brand/ } \\
\text { communications }\end{array}$ & 1994 Market Insight & Ivory Coast \\
\hline $\begin{array}{l}\text { Young Adult Females In The } \\
900000^{\prime} \text { s }\end{array}$ & Lifestyle & 1993 Leo Burnett (inferred) & Japan \\
\hline $\begin{array}{l}\text { Research Discussion Paper } \\
\text { Marlboro Smokers Research }\end{array}$ & $\begin{array}{l}\text { Brand image/ } \\
\text { communications }\end{array}$ & 1993 Hill N. Knowlton Asia & Hong Kong, Philippines, Korea, China (Proposals) \\
\hline $\begin{array}{l}\text { MISTA Motif Sort Test of Marlboro } \\
\text { Visuals }\end{array}$ & Communications & 1993 PM-EEC & Germany, Spain, Holland, Italy, France \\
\hline EEC Event Marketing & Communications & 1993 Author unknown & $\begin{array}{l}\text { EEC, EEMA, Germany, France, Italy, Spain, Finland, } \\
\text { Hungary, Sweden, Switzerland, Japan, Hong Kong, } \\
\text { Malaysia, Taiwan, Argentina, Brazil, Mexico, Venezuela }\end{array}$ \\
\hline $\begin{array}{l}\text { Int. Marlboro Image Dynamics } \\
\text { Study - Korea }\end{array}$ & $\begin{array}{l}\text { Lifestyle/brand/ } \\
\text { communications }\end{array}$ & 1994 Sinus (inferred) & Korea \\
\hline $\begin{array}{l}\text { Fax Proposal of Female Depth } \\
\text { Interview in Korea }\end{array}$ & Lifestyle & 1994 Hankook Rsch; Roh, I & Korea \\
\hline Competitive Brand Advertising & $\begin{array}{l}\text { Brand image/ } \\
\text { communications }\end{array}$ & 1994 Author unknown & Korea \\
\hline $\begin{array}{l}\text { European Lights Young Adult } \\
\text { Study }\end{array}$ & Brand/communications & 1994 RSG Marketing Rsch & Belgium, France, Germany, Italy, Netherlands \\
\hline
\end{tabular}

\section{RESULTS}

\section{International tobacco marketing research}

We identified three main categories of international market research conducted by Philip Morris: lifestyle research, brand studies, and advertising/communications testing (table 2 ).

\section{Lifestyle research}

The typical goal of lifestyle research is to gain an understanding of the needs, values, and beliefs of target consumers. A report prepared by market research firm Research International for Philip Morris summarised, "The crucial need is to identify how Marlboro 'fits' in the minds of Young Adult Smokers, by evaluating its positioning and appeal to the lifestyle, aspirations and needs of young smokers". ${ }^{21}$ Similarly, another report prepared for Philip Morris by Kelly Weedon Shute Advertising explained:

The objective is to get behind the consumer's thinking on a wide range of subjects-clothes...drinks...cigarettes... sources of information... hierarchy of key influences... 'self-images'... The intention is to isolate the specific influences and concerns of our key consumer groups identifying-their priorities...needs...ffears...desires/ likes...action seeking ${ }^{22}$

In 1989, advertising agency Leo Burnett conducted market research for Philip Morris designed "to provide insights into the 18 to 25 year old smoker target around the world...to get to know target as 'people'; to identify what/who is popular; to understand similarities/differences across 4 key world markets" (Germany, Switzerland, Japan, USA). ${ }^{23}$ Philip Morris conducted several additional studies into young adult consumer lifestyles (table 3). Between 1990 and 1994, Philip Morris conducted lifestyle studies in Hong Kong, ${ }^{24}$ China, Korea, Malaysia, and Taiwan, ${ }^{25} \mathrm{Japan}^{26}{ }^{27} \mathrm{Korea}^{28}$ Saudi Arabia, ${ }^{29}$ the Ivory Coast, ${ }^{30}$ Italy, ${ }^{31}$ Germany, ${ }^{32}$ France, Spain, Belgium, and the Netherlands. ${ }^{33}$

Philip Morris used this lifestyle research to chart value systems for young adult smokers all over the world. For example, a report written for Philip Morris by Research International contains a pie chart of the young adult male smoker (YAMS) value system (fig 1), and also contains a table of YAMS responses to sponsorship activities in Taiwan. It also contains an analysis of value trends. "Value trends that appear to be developing are: retention of some traditional values related to family...weakening of chauvinistic and conservative values towards women...extension of individual identity into more individualistic concerns...continued development of more materialistic values...". ${ }^{25}$ These value systems allowed Philip Morris to identify common values held by young adults across different markets.

\section{Brand research}

Philip Morris also sought to understand Marlboro's brand image in different markets. For example, the objectives for a 


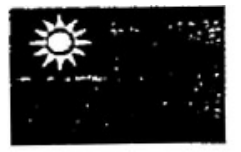

\section{YAMS Value System}

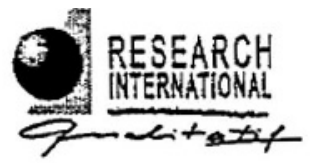

Figure 1 An example of a value system pie chart displaying values of young adult male smokers in Taiwan. This system provided a framework in which to analyse brand image and communications research. ${ }^{25}$

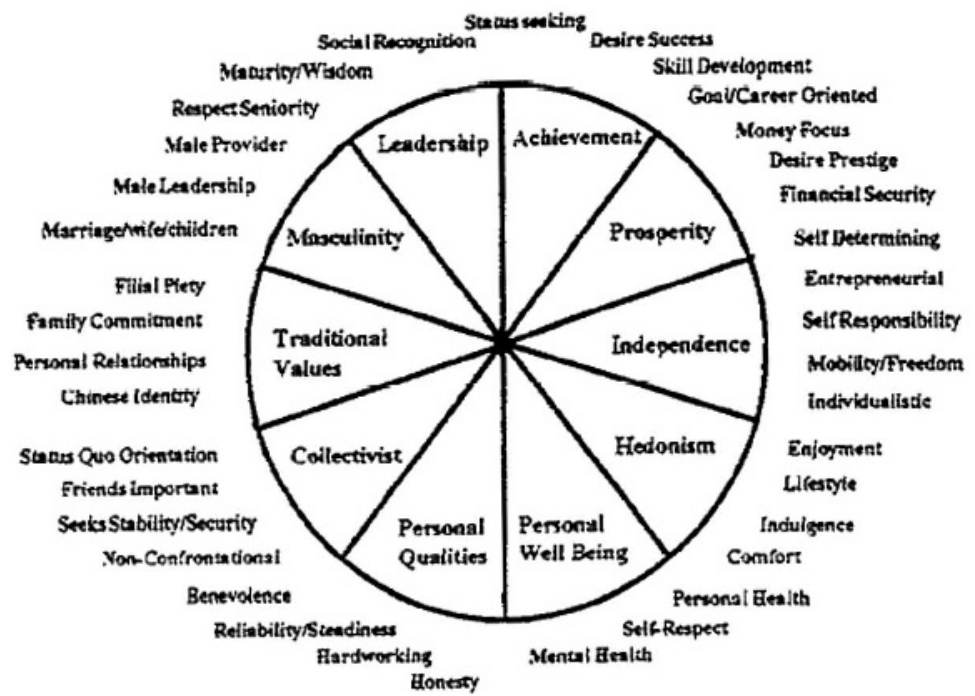

Marlboro Image Dynamics Study conducted for Philip Morris included, "How smokers perceive Marlboro in relation to the competition, what they see to be the key components of the Marlboro image, to what extent these image components correspond to the values of Europe's young generation...". ${ }^{29}$ The inquiry was not limited to Marlboro; as part of the study, researchers handed images of stick figures to respondents

\section{•In* Brands}

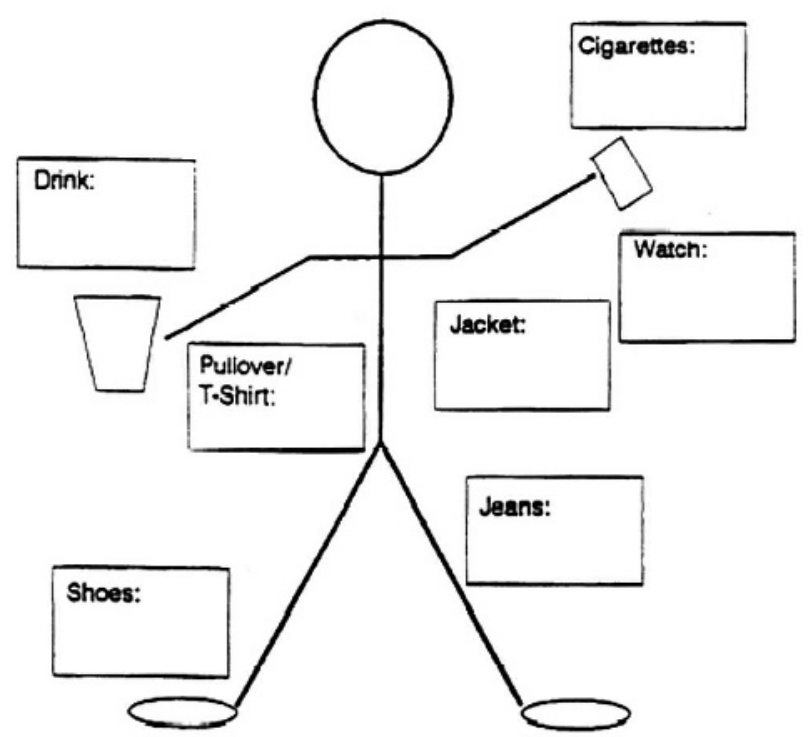

Figure 2 Image used in Philip Morris' Marlboro Image Dynamics Study. Researchers asked respondents "to dress it and equip it with all the accessories it needs to be 'in,"' recording the appropriate brand for the figure's jeans, jacket, shirt, watch, drink, and cigarettes. ${ }^{75}$ and asked them "to dress it and equip it with all the accessories it needs to be 'in,"' recording the appropriate brand for the figure's jeans, jacket, shirt, watch, drink, and cigarettes (fig 2). The researcher asked respondents to select the brand from their drawing that they identify with the most, and asked, "what words would you use to characterize this brand?". They repeated the question for a set of "international success brands" including Benetton, Swatch, Levi's, Coca-Cola, Pepsi and Nike, and for other cigarette brands including Camel, West, Lucky Strike, Gauloises Blondes, and Chesterfield. ${ }^{29}$

One strategy Philip Morris used to analyse complex images was the development of brand image frameworks. Brand image frameworks compartmentalise the various associations consumers make with particular brands and enable tobacco marketers to highlight and exploit key differences between brands. In their study of young adult male smokers ("YAMS") in Hong Kong, Research International created a framework of image associations for each of the examined brands, consisting of the brand's core image, the brand's user personality, associated brand communication imagery, and a set of rational assets (product strengths) associated with the brand..$^{24}$ The frameworks allowed for the comparison of brand features between competitors and other international brands (figs 3 and 4 ). ${ }^{24}$

Brand image associations become particularly useful to tobacco marketers interested in understanding how their brands correspond to consumer needs and values. In the same Research International study of Hong Kong YAMS, their values are represented as a pie chart and brand images are superimposed directly over the corresponding consumer values on the chart (fig 5). ${ }^{24}$ This graphical representation provided an important link between research projects, allowing Philip Morris to view the Marlboro brand strengths and weaknesses in relation to the consumer values described in its lifestyle research.

\section{Advertising communications research}

In Korea, Philip Morris' Image Dynamics Study also contained an extensive focus on advertising and communication efforts. ${ }^{34}$ For each area of communications research, 


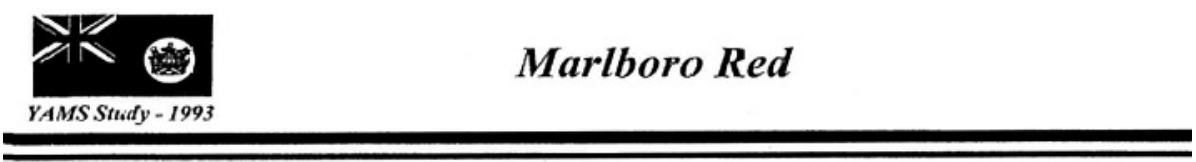

Figure 3 Examples of maps containing images and assets associated with Marlboro Red and Salem Lights developed for Philip
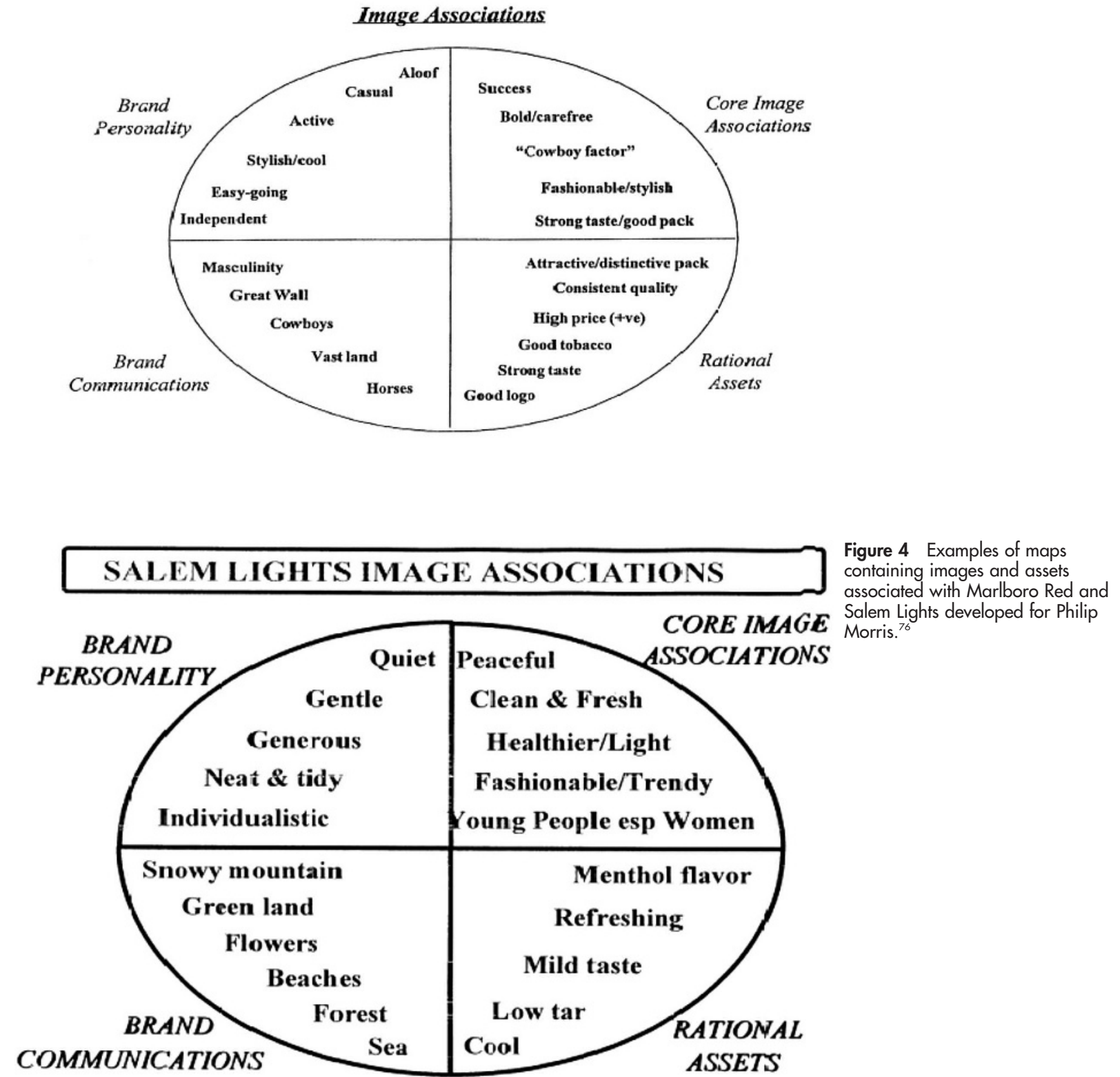

researchers first asked for spontaneous recall of any ads or promotional efforts, then probed respondents with a showboard of advertising images and specific questions regarding the advertising and promotional campaigns of Philip Morris, its competitors, and international brands from other industries.

What does he find particularly fascinating/interesting/ appealing about this advertising? What aspects of the ad does he like? What atmospheres, moods, emotions, etc, does it express?

What sort of world is shown in this advertising? How are people portrayed? Is this realistic? Does it match the respondents lifestyle/aspirations? How is it relevant to the respondent? Why/why not?...
What immediately comes to mind when the respondent thinks about Marlboro advertising? His impressions about advertising - does it appeal? Why/why not?... What images does Marlboro advertising portray/reinforce of Marlboro?... What sort of person does the advertising appeal to ${ }^{34}$

This consumer research included assessments of tobacco sponsorship and related promotional efforts. For example, a Korean study on young adult male smokers contained a section evaluating the effectiveness of movie stars in complementing Marlboro's image. They conclude that the Marlboro "image has been reinforced by a number of communications activities such as brand sponsorship but also because of the appeal of Chinese movie stars, who's cool/ 


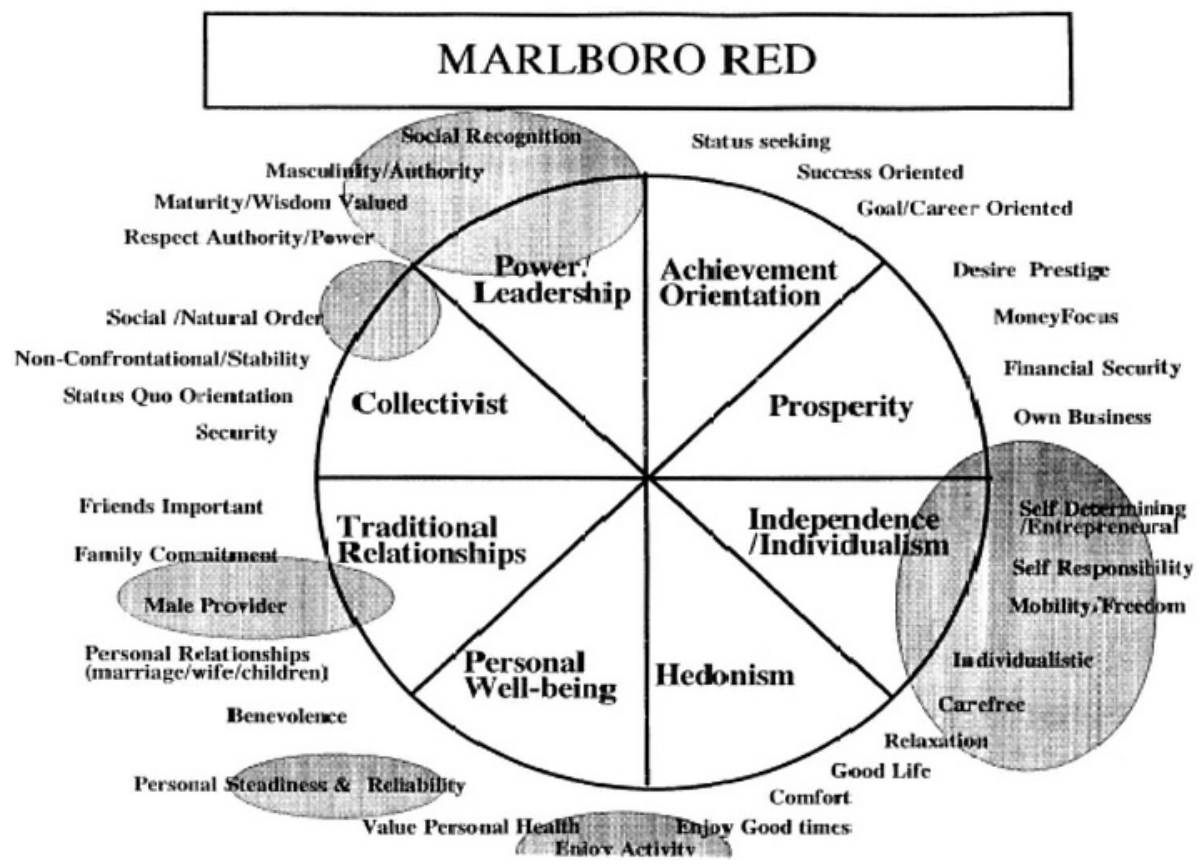

Figure 5 An example of a pie chart of consumer values for young adult smokers in Hong Kong and the corresponding image associations for Marlboro Red. This graphical representation highlights the Marlboro brand strengths and weaknesses in relation to the consumer values described in its lifestyle research. ${ }^{24}$

tough image complements Marlboro's traditional image in modern context (to some MR [Marlboro Red] smokers)". ${ }^{35}$

Young adults provided the best opportunity for a standardised approach

Young adults were the focus of much of PM's market research. The findings of converging lifestyles, attitudes, and values among young adults led to the development of standardised global marketing campaigns. ${ }^{23}$ For example, in a 1989 report for Philip Morris, Leo Burnett describes the emergence of a global generation of young adults:

Today, young adults [are] single most homogeneous group in history...our findings support existence of a 'global' community...target simultaneously exposed to same stimuli around the world...Today's media/marketing environment enables target to share common experiences, buy common products-creating a global community... ${ }^{23}$

Beyond these external influences, there are similarities on a more personal level...marked by three key developmental tasks: 1) establishing own identity/separating from parents, 2) developing close relationships outside family, 3) preparing for financial independence. ${ }^{23}$

Philip Morris identified the universal values and interests that played a role in the development of strategic marketing plans for young adults. For example, in a 1993 report, the Marlboro Worldwide Creative Review Committee outlined guidelines for international advertising. The report specifically highlighted the similarities between European and American young adult male smokers:

Findings from both continents were surprisingly similar. Young adult smokers of today have adopted a value system that differs from a decade prior while retaining some age group characteristics common from generation to generation.

Specifically, today's young adult smokers have rejected the materialism of the $80 \mathrm{~s}$ and reinterpreted/broadlined the concept of masculinity. Yet, independence and freedom is the common emotional thread which links today's young adults to previous generations. ${ }^{36}$

In addition to increasingly similar values among young adults worldwide, Philip Morris's research highlights the trend of increasingly "western" values among young adults in Asia in a series of studies conducted on young adult males in Japan. In 1993 Leo Burnett prepared market research reports for Philip Morris describing young adults in Japan. The young adult generation was dubbed "Dankai Jr's" (roughly analogous to "Baby Boomer $\mathrm{Jr}^{\prime} \mathrm{s}$ "), born between 1971 and 1974 and thus 19-22 years old when the research was conducted in 1993. In their report, Leo Burnett described young women ("Dankai Jr's") as leaders and magnifiers of new trends, and the authors referred to them as "the future target." ${ }^{26}$ Dankai Jr's were said to be "heavily influenced by American styles...strong sense of own taste, sense of fashion...strongly influenced by western culture, customs... lives are becoming less structured...act according to feeling". ${ }^{26}$

A Leo Burnett 1993 report prepared for Philip Morris contains a composite sketch of a Japanese young adult male, which appears remarkably similar to the American counterpart (fig 6), sharing clothing styles and even the same name brands. ${ }^{27}$ Also in 1993 in Hong Kong, Philip Morris released "Red Hot Hits", a CD of pop music with youthful models dressed in American clothing on the label. ${ }^{37}$ These examples highlight Philip Morris' awareness of a convergence of young adult culture, in particular among young adults in Japan, Hong Kong and the west.

\section{Standardising Marlboro promotions}

Following a period of extensive market research in emerging international economies in the early 1990s Philip Morris pursued a globally synchronised marketing campaign to develop a global Marlboro brand identity. Philip Morris standardised worldwide promotional efforts and Marlboro's core brand identity, while retaining some of the strengths of an adaptive local strategy in their copy design for specific advertisements. 


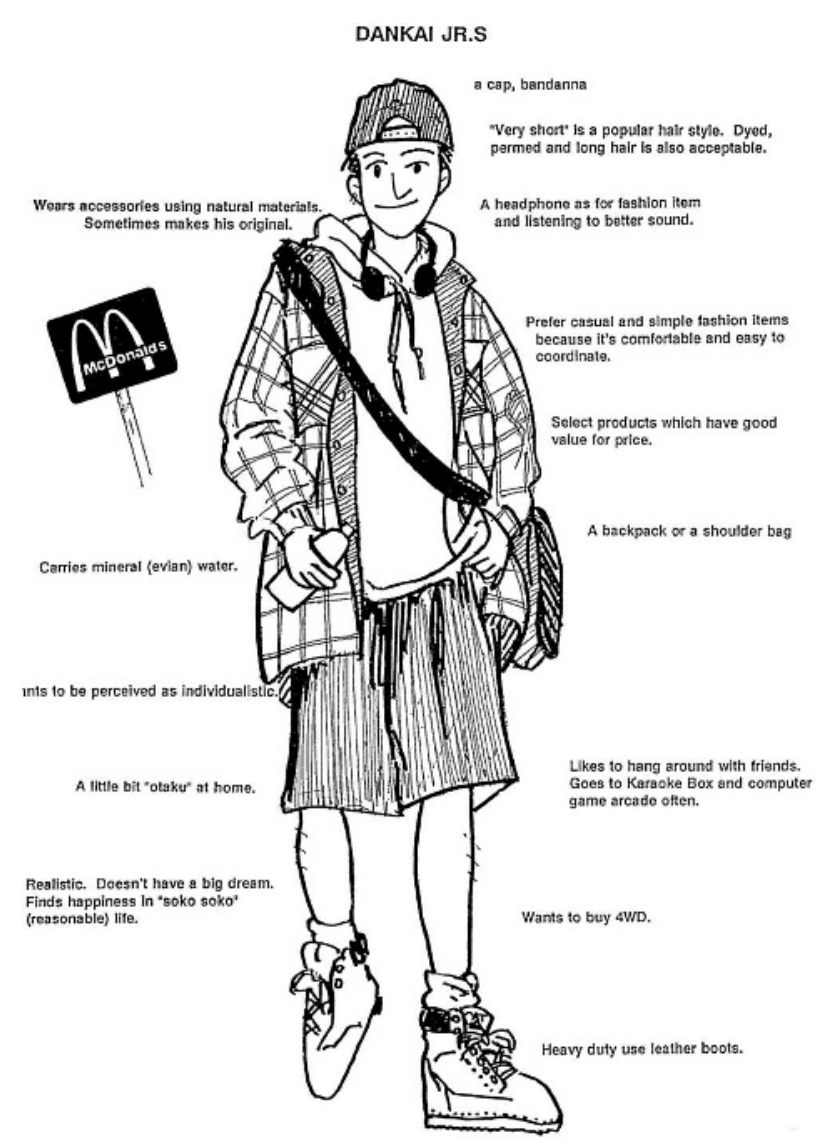

Figure 6 A composite sketch of a Japanese young adult male from a 1993 Leo Burnett study for Philip. The young Japanese male appears remarkably similar to his American counterpart, sharing clothing styles and even the same name brands. ${ }^{27}$

Philip Morris CEO Geoffrey Bible called a worldwide Marlboro meeting in 1992 to discuss plans for worldwide standardisation of brand identity and advertising efforts. The result of the meeting with members from Philip Morris USA and International resulted in a focus on the "similarities between PMUSA and PMI business issues and the young adult male smoker's likes and dislikes" ${ }^{38}$ The meeting marked the establishment of the Marlboro Worldwide Creative Review Committee (MWCRC), a group charged with the development and regulation of all international marketing messages with the following goals:

...ensure that Marlboro communication is appealing to young adult smokers, ...to ensure consistency of execution worldwide, this both in terms of visual treatment and copy layouts; and...to ensure that we have sufficient creative materials at all times to satisfy worldwide needs.

Our first endeavor was to create a global advertising brief. One merged from gaining deeper insights into our consumers' values from markets around the world. The brief emanates from the core values of Marlboro...selfconfidence, freedom of choice, leadership, strength, independence and adventure. The advertising proposition is 'Come to where the flavor is...Come to Marlboro Country'. The brief sets the direction for development of a pool of ads that, through themes, interprets the core values of Marlboro Country and the cowboy. ${ }^{39}$

The MWCRC consisted of top executives of Philip Morris USA, Philip Morris International, regional marketing heads, and select employees of Leo Burnett. ${ }^{39}$ The mission of the MWCRC was to "ensure a shared worldwide vision for Marlboro. Consistent marketing strategy. Consistent creative/ promotional execution," and to act as a "forum for shared experiences" ${ }^{38}$ The first meeting of the MWCRC called for the creation of a Marlboro Worldwide Brief to be distributed to all marketing regions..$^{40}$ In the fall of 1993 the committee released their first worldwide pool, consisting of four commercials and 63 print ads, aiming to "Link Marlboro to relevant frontier values (Freedom, control, independence, mastery, timeless opportunity), Encompass full range of contemporary masculine values (Strong, sensitive, caring, in harmony with nature)". ${ }^{41}$

The success of the coordinated domestic and international strategy was attributed to the shared interest of Philip Morris USA and Philip Morris International, and the committee's ability to target new generations of young adults.

...every year there are new legal age smokers to educate on the core values of Marlboro.

Just as we have found a new theme-camaraderie-that is important to YAS, we can expect that new themes may emerge to effectively communicate to new generations. And while exploring new themes is important, there is no doubt that the core values of Marlboro's image are and remain key to preserving Marlboro's heritage. ${ }^{42}$

It was critical to establish a consistent image for Marlboro internationally among young adults in particular:

We will have product consistency worldwide...we will maintain a consistent brand message everywhere. This is critical in our newer markets where the consumer has not been exposed to Marlboro's imagery and for our new generations of YAS. ${ }^{42}$

The global standardisation strategy included sponsorship efforts as well:

Event marketing: Market co-ordination and support; Markets must consolidate their resources behind our existing programs, increasing cooperation on budget and event planning... We want to ensure consistency of execution, appearance, measurement of all brand event marketing programs. All contracts and designs will be handled by $H Q .{ }^{42}$

The implementation of the MWCRC and the global advertising pool ushered the development of a standardised research system for the evaluation of the worldwide pool. In order to gauge the effectiveness of their new worldwide pool, Philip Morris developed the Marlboro International Study for Testing and Advertising (MISTA), a standardised research system for gathering consumer insights on print campaigns.

While TV and Cinema remain critical components of the marketing mix, Print has become an essential tool. To this end we have implemented a research system to ensure the value and effectiveness of our print and outdoor themes to the consumer. This research system is called MISTA (Marlboro International Study for Testing and Advertising). The technique was developed jointly with PMI, the Regions, and Leo Burnett. For the first time we have a consistent methodology and common terminology for reviewing print amongst consumers worldwide. ${ }^{39}$ 
In 1995, Philip Morris conducted a series of MISTA studies throughout Asia, Europe, and the Middle East. That year, Philip Morris and Leo Burnett conducted MISTA studies in Hong Kong, Korea, China (Shanghai), Germany, Spain, the Netherlands, Greece, Czech Republic, Hungary, Israel, Kazakhstan, Poland, Turkey, and Ukraine. ${ }^{39}$

\section{DISCUSSION}

This analysis outlines how Philip Morris built Marlboro into a global brand. Market research provided the backbone for Philip Morris's global strategic marketing plans. This market research falls into three basic categories: research into lifestyles and attitudes, research about brand image and equity, and research on the effectiveness of specific communications messages. These strategies have been carried out for many years in the USA, ${ }^{17}$ Canada, ${ }^{43}$ and the UK. ${ }^{44}$ These research efforts focused on young adults as a priority target for both research and marketing efforts, and increased standardisation of promotional strategies between global markets. The commonality Philip Morris found in the emerging core values of young adults led to globally standardised branding efforts and standardised advertising messages for Marlboro. These efforts are particularly evident in worldwide sponsorship efforts that appeal to young people, such as those documented in the Formula One circuit. ${ }^{45}{ }^{46}$ While striving for a global brand identity, Philip Morris used specific advertising communications research to tailor executions to specific regions or markets.

An understanding of these global promotion strategies provides opportunities to develop more relevant tobacco control policies and more effective counter-marketing messages. These strategies suggest the global tobacco control community should: (1) increase utilisation of market research techniques to plan tobacco control interventions; (2) focus on young adults and their common values; (3) focus on brand image, to create a global anti-tobacco brand identity and to undermine tobacco brand images; (4) promote global standardisation of successful tobacco control strategies from different parts of the world.

As the most popular and largest selling tobacco brand in the world, Marlboro is an example of an effective system of market research and strategic planning that can be used to inform tobacco policy and counter-marketing efforts. Public health researchers can understand the relevant core values of target audiences by conducting original market research or by utilising the research findings reported in internal tobacco industry documents. ${ }^{47}$ Important young adult values and needs are described in tobacco market research as: independence, coming of age, hedonism, freedom, and comfort. These values transcend specific regional values, and are crucial to nearly all tobacco marketing efforts. Tobacco control messages should aim to break the association between these values and tobacco brand images. In some cases, the tobacco industry's choice to focus on a specific value, such as hedonism, as most important to young adults could be questioned or countered with another value (such as independence) common to this group. In other cases, false associations (for example, advertisements that connect smoking and freedom) can be countered directly with attacks on tobacco brand images, as in "ad busting" or "ad jamming". ${ }^{48}$

Tobacco control policies that restrict only specific advertising executions, such as limiting advertising to publications with adult readership, eliminating cartoon characters ${ }^{49}$ or specific text copy leave the brand image and the appeal to young adult core values intact. Tobacco marketers have already become adept at circumventing advertising restrictions while preserving their brand identities. ${ }^{50-52}$ An approach focusing on the underlying values that appeal to young adults worldwide may be more realistic and more effective in the long run than efforts focusing on specific advertising executions or campaigns.

Young adults provide the best opportunity for globally standardised tobacco control messages. Young adults around the world identify with their American peers and vice versa. The Marlboro brand and smoking in general has been promoted as western or American, even while tobacco use is on the decline in America. This irony should not be lost on the international public health community, and can be used to counter tobacco advertising pairing cigarette brands with western images of success. Researchers in Australia recently showed that youth in the USA, Britain, and Australia appraise anti-smoking messages and ads similarly. ${ }^{53}$ This suggests that counter-marketing messages that resonate with young adults in one community may hold promise as global anti-tobacco messages for young adults.

Global counter marketing efforts should also focus on brand image. For example, the Legacy foundation's "Truth" campaign built a salient anti-tobacco brand in the USA ${ }^{54-57}$ that may be leveraged to appeal internationally among young people who share similar core values. A focus on brands also implies tobacco control messages should attack tobacco brand images. "Ad busting" may be the most direct attack. ${ }^{58}$ While such practices are often seen in "the practice of parodying advertisements and hijacking billboards in order to drastically alter their messages" ${ }^{\prime,}{ }^{58}$ copyright laws or graffiti prohibitions in some countries make such direct attacks difficult. The focus for tobacco control should be, as Naomi Klein explains, "not standard ad-parodies but interceptions-counter-messages that hack into a corporation's own method of communication to send a message directly at odds with the one that was intended". ${ }^{58}$ Brands also present an opportunity for industry denormalisation. People are more likely to identify a heavily advertised brand name such as Marlboro or Camel rather than the parent company such as Philip Morris (now Altria) or British American Tobacco. News media attention and counter marketing highlighting unethical tobacco industry behaviour, such as smuggling, targeting vulnerable populations, ${ }^{60-62}$ or environmental abuses, $^{63}$ should draw attention not only to the tobacco company but to the major brands they own.

Over a decade ago, Philip Morris adopted a formal strategy of brand standardisation across international markets, allowing some regional adaptation in tailoring advertising messages. The tobacco control community should follow suit and adopt a globally standardised set of best practices for tobacco control messages. The international public health community could capitalise on the advantages of standardisation using messages that have proven successful in the USA and elsewhere, such as clean indoor air ${ }^{64}$ and industry denormalisation. ${ }^{54-57}$ Specific treatments could be adapted locally based on regional nuances and preferences, but the core messages should target shared values.

Counter-marketing efforts, especially those that denormalise the tobacco industry, can serve to break the positive association between core cultural values and tobacco brands. There is evidence that counter-marketing is an effective strategy. In the USA between 1967 and 1971, tobacco counter-marketing under the Fairness Doctrine is widely recognised as contributing to decreases in smoking. ${ }^{66-68}$ In addition a number of studies have shown anti-tobacco counter-marketing to be effective in reducing cigarette consumption. $^{69}$ A 1977 anti-smoking campaign conducted in Norway led to a $4 \%$ reduction in tobacco sales and encouraged 100000 smoking cessation efforts. ${ }^{70}$ In Australia, a recent cohort study showed significant decreases in cigarette consumption among individuals exposed to an anti-smoking campaign. ${ }^{71}$ Studies of counter marketing 


\section{What this paper adds}

Prior studies describe the emergence of new markets for tobacco products and the exportation of successful marketing strategies from developed countries to the developing world. However, much of the research to date has been region specific, highlighting the marketing efforts and strategies in specific countries. No prior studies describe the market research strategies tobacco companies utilised in developing worldwide promotional strategies.

This study examines Philip Morris's market research and strategic marketing plans for their flagship brand Marlboro. Philip Morris standardised their international brand identity and advertising messages to target shared values of young adults described in market research in different countries. These findings suggest that the tobacco control community should target young adults, appeal to the shared values targeted by tobacco companies, and standardise worldwide counter-marketing efforts using messages that have proven successful in individual countries.

efforts in the state of California show counter-marketing to be effective in reducing cigarette consumption in the state..$^{72}$

A comprehensive global ban on tobacco advertising and promotion is an international policy that most directly answers globally standardised tobacco marketing strategies. A standardised global ban would rob tobacco companies of their ability to substitute traditional ads with new forms of media and new promotional strategies in different countries. $^{68} 74$ The Framework Convention on Tobacco Control's comprehensive ban on advertising, trademark diversification, sponsorship, and promotions is a first step in the international battle against global tobacco brands and marketing. A logical next step would be the development of standardised counter-marketing messages targeting the same shared values targeted by transnational tobacco corporations. A combined worldwide policy regulating the marketing practices of the tobacco industry through global restrictions and a standardised counter-marketing effort is the best practice for combating the globalisation of tobacco.

\section{ACKNOWLEDGEMENTS}

The authors wish to thank Dr Stan Glantz and Dr Tim Dewhirst for guidance and helpful comments on the manuscript.

\section{Authors' affiliations}

N Hafez, P M Ling, Center for Tobacco Control Research and Education, Department of Medicine, Division of General Internal Medicine, University of California, San Francisco, San Francisco, California, USA

This work was supported by the Minority Training Program in Cancer Control Research, National Cancer Institute, grant \#R25CA78583 and National Cancer Institute Grant number CA-87472

Competing interests: none declared

\section{REFERENCES}

1 Yach D, Bettcher D. Globalisation of tobacco industry influence and new global responses. Tobacco Control 2000;9:206-16.

2 Seimon T, Mehl GL. Strategic marketing of cigarettes to young people in Sri Lanka: "go ahead--I want to see you smoke it now". Tobacco Control 1998;7:429-33.

3 O'Sullivan B, Chapman S. Eyes on the prize: transnational tobacco companies in China 1976-1997. Tobacco Control 2000;9:292-302.

4 Szilagyi T. Hungary introduces a total ban on tobacco advertising. Tobacco Control 2002;11:79-81.

5 Chapman S. "The contemporary, irreverent brand of youth with an independent streak": BAT's youth promotions in Myanmar. Tobacco Control 2004; 13:93-4.
6 Reynolds C. Tobacco advertising in Indonesia: "the defining characteristics for success". Tobacco Control 1999;8:85-8.

7 British American Tobacco. Our Regions; 200418 March 2004 www.bat.com (Accessed 27 July 2004).

8 Zhu SH, Li D, Feng B, et al. Perception of foreign cigarettes and their advertising in China: a study of college students from 12 universities. Tobacco Control 1998;7:134-40.

9 Emri S, Bagci T, Karakoca Y, et al. Recognition of cigarette brand names and logos by primary schoolchildren in Ankara, Turkey. Tobacco Control 1998;7:386-92.

10 Stanton HJ. The Marlboro Man on coral beaches. Tobacco Control 1996;5:7-8.

11 Simpson D. Hong Kong: Marlboro tries it on (the pack). Tobacco Control 2002;11:171

12 Warner KE, Connolly GN. The global metastasis of the Marlboro Man. Am J Health Promot 1991;5:325-7.

13 Goldberg M. American Media and the Smoking-related Behaviors of Asian Adolescents. Journal of Advertising Research 2003:2-11.

14 Kotler PA, G. Principles of marketing. Upper Saddle River: Prentice Hall, 1999.

15 Bartecchi CE, MacKenzie TD, Schrier RW. The global tobacco epidemic. Sci Am 1995;272(5):44-51

16 Altria Group Inc. Altria Group Inc. 2003 Annual Report. Business Review. International Tobacco; 2004. http://www.altria.com/AnnualReport2003/ ar2003_05_0200.asp (Accessed 27 July 2004).

17 Ling PM, Glantz SA. Why and how the tobacco industry sells cigarettes to young adults: evidence from industry documents. Am J Public Health 2002;92:908-16.

18 Leo Burnett Co. (inferred). Philip Morris Asia 'Global Generation' Presentation, 901200. Dec 1990. Bates No. 2022643604/3623. http:// legacy.library.ucsf.edu/tid/qdc85e00(est.) (Accessed 27 Jul 2004).

19 Philip Morris International. Outline of Marketing Research Conducted at Philip Morris International. Aug 1986. Bates No. 2501040186/0199. http://legacy.library.ucsf.edu/tid/qqs19e00(est.) (Accessed 13 Jul 2004).

20 Malone RE, Balbach, eds. Tobacco industry documents: treasure trove or quagmire? Tobacco Control 2000;9(3):334-8.

21 Research International (inferred). Philip Morris Asia: Research Discussion Paper Marlboro Smokers Research. Mar 1993. Bates No. 2504029339/ 9347. http://legacy.library.ucsf.edu/tid/rcu19e00(est.) (Accessed 13 Jul 2004).

22 Kelly Weedon Shute Advertising. Philip Morris Cigarette Marketing a New Perspective. Nov 1989. Bates No. 2501057693/7719. http:// legacy.library.ucsf.edu/tid/lti49e00(est.) (Accessed 13 Jul 2004).

23 Leo Burnett Agency. Global Generation Young Adult Smokers around the World. 20 Nov 1989. Bates No. 2043087329/7436. http:// legacy.library.ucsf.edu/tid/dwq03e00 (Accessed 13 Jul 2004).

24 Research International Asia. Hong Kong Yams Study 930000 Philip Morris Asia Inc. A Study of Values, Lifestyles and Brand Images among Hong Kong Young Adult Male Smokers. 2 Dec 1993. Bates No. 2504029966/0142. http://legacy.library.ucsf.edu/tid/mcu19e00 (Accessed 14 Jul 2004).

25 Hamel and Prahalad. A Study of Values, Lifestyles and Brand Images among Taiwanese Young Adult Male Smokers. 1991. Bates No. 2504053019/ 3024. http://legacy.library.ucsf.edu/tid/sex32e00(est.) (Accessed 14 Jul 2004).

26 Leo Burnett Agency (inferred). Young Adult Females in the 900000's What's Hot Amongst Our Target. Jun 1993. Bates No. 2500134664/4699. http:// legacy.library.ucsf.edu/tid/nam 19e00(est.) (Accessed 14 Jul 2004).

27 Leo Burnett Agency. Young Male Adults in Japan Emerging Trends \& Tastes in 90's. May 1993. Bates No. 2500134701/4775. http:// legacy.library.ucsf.edu/tid/zbm 19e00(est.) (Accessed 14 Jul 2004).

28 Sinus (inferred). International Marlboro Image Dynamics Study Korea. Mar 1994. Bates No. 2504033659/3701. http://legacy.library.ucsf.edu/tid/ joi81c00(est.) (Accessed 14 Jul 2004).

29 Sinus (inferred). International Marlboro Image Dynamics Study an International Qualitative Study. 18 Mar 1993. Bates No. 2500134818/ 4837. http://legacy.library.ucsf.edu/tid/ham 19e00(est.) (Accessed 14 Jul 2004)

30 Market Insight. Marlboro Image Dynamics Study in the lvory Coast 940300. Mar 1994. Bates No. 2501055626/5716. http://legacy.library.ucsf.edu/ $\mathrm{tid} /$ jws 19e00(est.) (Accessed $30 \mathrm{Jul} 2004$ ).

31 Herzog P. Young Adult Smokers in Italy. 20 Dec 1992. Bates No. 2500134614/4618. http://legacy.library.ucsf.edu/tid/dbm $19 \mathrm{e} 00$ (Accessed 14 Jul 2004)

32 Leo Burnett Agency. Global Generation Young Adult Smokers around the World. 25 Jan 1990. Bates No. 2048571219/1298. hitp:// legacy.library.ucsf.edu/tid/csb92e00 (Accessed 14 Jul 2004)

33 PM-EEC. Marlboro Red Eec Marketing Review. Aug 1992. Bates No. $2501120912 / 0977$. http://legacy.library.ucsf.edu/tid/mru32e00(est.) (Accessed 14 Jul 2004).

34 Sinus (inferred). International Marlboro Image Dynamics Study Korea. Mar 1994. Bates No. 2504033379/3421. http://legacy.library.ucsf.edu/tid/ woq19e00(est.) (Accessed 14 Jul 2004)

35 non. Competitive Brand Advertising. Jul 1994. Bates No. 2504033423/ 3439. http://legacy.library.ucsf.edu/tid/yoq19e00(est.) (Accessed 14 Jul 2004).

36 Marlboro Creative Review Committee. Marlboro Worldwide Creative Issues and Guidelines 930000 'Facing the Changing Attitudinal Values of Our Key Consumer Audience in the $900000^{\prime} \mathrm{s}^{\prime}$. 1993. Bates No. 2500058104/8113. http://legacy.library.ucsf.edu/tid/nri19e00(est.) (Accessed 15 Jul 2004). 
37 INFACT. Global Aggression: The Case for World Standards and Bold US Action Challenging Philip Morris and RJR Nabisco; 1998. http:// www.infact.org/98par.html (Accessed 27 July 2004).

38 PMI PMI. Marlboro Strategy Meeting 930414. 14 Apr 1993. Bates No. 2500144349/4576. http://legacy.library.ucsf.edu/tid/vqc42e00 (Accessed 7 Jan 2005).

39 Philip Morris International. Marlboro for the 90 s and Beyond. No Date. Bates No. $2501108735 / 8816$. http://legacy.library.ucsf.edu/tid/wuu32e00 (Accessed $15 \mathrm{Jul}$ 2004)

40 Anon. Marlboro Strategy Meeting. 14 Apr 1993. Bates No. 2501304775/ 5002. http://legacy.library.ucsf.edu/tid/ift39e00 (Accessed 15 Jul 2004).

41 PM-EEC. Marlboro Creative Development Advertising Update. Oct 1993. Bates No. 2501319215/9223. http://legacy.library.ucsf.edu/tid/ vzr22e00(est.) (Accessed $15 \mathrm{Jul} 2004$ ).

42 Anon. Eec Event Marketing. Aug 1993. Bates No. 2501319419/9458. http://legacy.library.ucsf.edu/tid/odt39e00 (est.) (Accessed 15 Jul 2004).

43 Pollay RW. Targeting youth and concerned smokers: evidence from Canadian tobacco industry documents. Tobacco Control 2000;9:136-47.

44 Hastings G, MacFadyen L. A day in the life of an advertising man: review of internal documents from the UK tobacco industry's principal advertising agencies. BMJ 2000;321:366-71.

45 Dewhirst T, Hunter A. Tobacco sponsorship of Formula One and CART auto racing: tobacco brand exposure and enhanced symbolic imagery through cosponsors' third party advertising. Tobacco Control 2002;11:146-50.

46 Carlyle J, Collin J, Muggli ME, et al. British American Tobacco and Formula One motor racing. BMJ 2004;329:104-6.

47 Ling PM, Glantz SA. Using tobacco-industry marketing research to design more effective tobacco-control campaigns. JAMA 2002;287:2983-9.

48 Chapman S. Civil disobedience and tobacco control: the case of BUGA UP. Billboard Utilising Graffitists Against Unhealthy Promotions. Tobacco Control 1996;5:179-85.

49 National Association of Attorneys General. Master Settlement Agreement; 1998. http://www.naag.org/upload/1032468605_cigmsa.pdf (Accessed 27 July 2004).

50 Carter SM. Going below the line: creating transportable brands for Australia's dark market. Tobacco Control 2003;12(suppl III):iii87-94.

51 Carter SM. The Australian cigarette brand as product, person, and symbol. Tobacco Control 2003;12(suppl III):iii79-86.

52 Carter SM. New frontier, new power: the retail environment in Australia's dark market. Tobacco Control 2003; 12(suppl III):iii95-101.

53 Wakefield $M$, Durrant $R$, Terry-McElrath $Y$, et al. Appraisal of anti-smoking advertising by youth at risk for regular smoking: a comparative study in the United States, Australia, and Britain. Tobacco Control 2003; 12(suppl II):ii82-6.

54 Farrelly MC, Healton CG, Davis KC, et al. Getting to the truth: evaluating national tobacco countermarketing campaigns. Am J Public Health 2002;92:901-7.

55 Niederdeppe J, Farrelly MC, Haviland ML. Confirming "truth": more evidence of a successful tobacco countermarketing campaign in Florida. Am J Public Health 2004;94:255-7.

56 Sly DF, Trapido E, Ray S. Evidence of the dose effects of an antitobacco counteradvertising campaign. Prev Med 2002;35:51 1-8.

57 Sly DF, Heald GR, Ray S. The Florida "truth" anti-tobacco media evaluation design, first year results, and implications for planning future state media evaluations. Tobacco Control 2001;10:9-15.

58 Klein N. No logo. New York: Picador, 2000.

59 Gilmore $\mathbf{A B}$, McKee M. Moving East: how the transnational tobacco industry gained entry to the emerging markets of the former Soviet Union-part I: establishing cigarette imports. Tobacco Control 2004;13:143-50.
60 Balbach ED, Gasior RJ, Barbeau EM. R.J. Reynolds' targeting of African Americans: 1988-2000, Am J Public Health 2003;93:822-7.

61 Muggli ME, Pollay RW, Lew R, et al. Targeting of Asian Americans and Pacific Islanders by the tobacco industry: results from the Minnesota Tobacco Document Depository. Tobacco Control 2002;11:201-9.

62 Yerger VB, Malone RE. African American leadership groups: smoking with the enemy. Tobacco Control 2002;11:336-45.

63 Novotny TE, Zhao F. Consumption and production waste: another externality of tobacco use. Tobacco Control 1999;8:75-80.

64 Stevens C. Designing an effective counteradvertising campaign-California. Cancer 1998:83(12 suppl Robert):2736-41.

65 Goldman LK, Glantz SA. Evaluation of antismoking advertising campaigns. JAMA 1998;279:772-7

66 Wakefield $M$, Flay $B$, Nichter $M$, et al. Effects of anti-smoking advertising on youth smoking: a review. J Health Commun 2003;8:229-47.

67 Warner KE. The effects of the anti-smoking campaign on cigarette consumption. Am J Public Health 1977;67:645-50

68 Warner KE, Goldenhar LM. The cigarette advertising broadcast ban and magazine coverage of smoking and health. J Public Health Policy 1989;10:32-42.

69 Flay BR. Mass media and smoking cessation: a critical review. Am J Public Health 1987;77:153-60.

70 Hauknes A. Results form an evaluation of a special smoking and health information campaign in Norwegian newspapers and on television in 1977. In: Lethar D, Hastings G, Davies J, eds. Health education and media. Oxford: Pergamon Press, 1981.

71 Dwyer T, Pierce JP, Hannam CD, et al. Evaluation of the Sydney "Quit. For Life" anti-smoking campaign. Part 2. Changes in smoking prevalence. Med J Aust 1986; 144:344-7.

72 Hu TW, Sung HY, Keeler TE. Reducing cigarette consumption in California: tobacco taxes vs an anti-smoking media campaign. Am J Public Health 1995;85:1218-22.

73 Hu TW, Sung HY, Keeler TE. The state antismoking campaign and the industry response: the effects of advertising on cigarette consumption in California. Am Econ Rev 1995;85(2):85-90.

74 Simonich WL. Banning tobacco advertising: boon to the industry? JAMA 1993;270:321-2

75 Lebensweittorschung (Sinus). International Marlboro Image Dynamics Study an International Qualitative Study. May 1993. Bates No. 2504053186/ 3215. http://legacy.library.ucsf.edu/tid/jvv19e00(est.) (Accessed 14 Jul 2004).

76 Philip Morris Asia Inc. Hong Kong Yams Study 930000 a Study of Values, Lifestyles, and Brand Images among Hong Kong Young Adult Male Smokers. Jan 1994. Bates No. 2504053220/3299. http://legacy.library.ucsf.edu/ tid/ezw32e00(est.) (Accessed 29 Jul 2004)

77 Aaker DA. Building strong brands, 1 st ed. New York: Free Press (Simon \& Schuster, Inc), 1996

78 Keller KL. Conceptualizing, Measuring, and Managing Customer-Based Brand Equity. Journal of Marketing 1993;57:1-22.

79 Aaker DA, Joachimsthaler E. Brand leadership, 1st ed. New York: Free Press (Simon \& Schuster, Inc), 2000.

80 Aaker DA. Brand portfolio strategy: creating relevance, differentiation, energy, leverage, and clarity, 1 st ed. New York: Free Press (Simon \& Schuster, Inc), 2004.

81 Anon. Advertising Copy Research. 20 Oct 1975. Bates No. 680105786/5835. http://legacy.library.ucsf.edu/tid/wyc50f00 (Accessed 14 Jul 2004) 